\title{
STIMULASI PERKEMBANGAN PADA ANAK USIA PRASEKOLAH
}

\section{Septriani Renteng}

Program Studi Ilmu Keperawatan, Universitas Sam Ratulangi, Indonesia

Email: septriani.tri@gmail.com

\section{Abstract}

Improving the quality of health in children is the government's effort in increasing productive human resources. Improving the health of children with optimal attention to the stages of development, especially the golden age of children. Development is an important factor in the life of preschoolers because it will determine the development of children in the next age. But the development of children has not become the main priority of parents in child care. This condition is very impact on the provision of developmental stimulation in preschoolers by the parents. Efforts that can be done by nurses in overcoming these problems by running the role nurse are care providers. Stimulation aims to improve the stages of development of preschoolers. The method used in this practice is the case study of 118 preschool children in five kindergartens in Curug Urban Village. Based on the evaluation showed an increase in the development of preschool children as much as 19\%. The results of the evaluation activities can be concluded the program can be used in improving the development of preschoolers.

Keywords: development; pre-school children; friend

\begin{abstract}
Abstrak
Peningkatan kualitas kesehatan pada anak merupakan upaya pemerintah dalam peningkatan sumber daya manusia yang produktif. Peningkatan kesehatan anak dengan perhatian optimal terhadap tahapan perkembangan khususnya masa keemasan anak yaitu usia prasekolah. Perkembangan merupakan faktor penting di kehidupan anak usia prasekolah karena akan menentukan perkembangan anak diusia yang selanjutnya. Namun saat ini perkembangan anak belum menjadi prioritas utama orang tua dalam pengasuhan anak. Kondisi ini sangat berdampak terhadap pemberian stimulasi perkembangan pada anak usia prasekolah oleh orang tua. Upaya yang dapat dilakukan oleh perawat dalam mengatasi permasalahan tersebut dengan menjalankan peran sebagai pemberi layanan berupa stimulasi perkembangan. Tujuan penelitian ini mengambarkan tahapan perkembangan anak prasekolah setelah dilakukan stimulasi perkembangan. Metode yang digunakan dalam adalah studi kasus kepada 118 anak usia prasekolah di lima TK di Kelurahan Curug. Berdasarkan hasil evaluasi menunjukan adanya peningkatan perkembangan pada anak usia prasekolah sebanyak $19 \%$ sehingga dapat disimpulkan dapat digunakan dalam meningkatkan perkembangan anak.
\end{abstract}

Kata kunci: anak usia prasekolah; perkembangan anak usia prasekolah; sahabat 
Coresponden Author

Email: septriani.tri@gmail.com

Artikel dengan akses terbuka dibawah lisensi

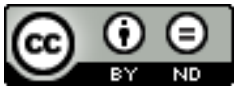

\section{Pendahuluan}

Pembangunan kesehatan oleh bangsa Indonesia bertujuan dalam meningkatkan kesadaran, kemauan, dan kemampuan untuk hidup sehat sebagai upaya menciptakan sumber daya manusia yang produktif. Anak usia prasekolah merupakan salah satu target dalam peningkatan kesehatan karena sebagai generasi penerus bangsa. Salah satu komponen kesehatan pada anak usia prasekolah yang menjadi prioritas adalah tahapan perkembangan anak. Perkembangan pada anak sangat berpengaruh terhadap kesehatan anak di usia selanjutnya. Oleh karena itu diperlukan peran orang tua dalam melakukan pengasuhan kepada anak.

Pengasuhan pada anak yang dilakukan oleh orang tua mengoptimalkan dua faktor pada anak yaitu faktor pertumbuhan dan perkembangan. Pencapaian kualitas pertumbuhan dipengaruhi dengan pemenuhan gizi pada anak. Hal ini tergambar dari beberapa penelitian yang dilakukan yang menyatakan adanya hubungan yang positif antara pemenuhan nutrisi dengan tahapan perkembangan (Uce, 2017). Pencapaian perkembangan yang optimal selain dipengaruhi gizi anak juga dipengaruhi oleh pemberian stimulasi perkembangan (Kemenkes RI, 2016).

Stimulasi perkembangan adalah kegiatan yang bertujuan untuk meningkatan kemampuan anak untuk mencapai tugas tertentu yang sesuai dengan tahapan perkembangan (Sudarsih, Syafrial, \& Bahar, 2014). Namun yang terjadi orang tua lebih memahami konsep pertumbuhan pada anak dibandingkan perkembangan anak. Kondisi ini tergambar dari hasil wawancara kepada orang tua di TK Kelurahan Curug yang mengambarkan bahwa perkembangan adalah pemantauan berat badan anak secara berkala. Selain itu berdasarkan hasil survey yang dilakukan kepada orang tua dengan topik perkembangan di TK Kelurahan Curug teridentifikasi hanya $63 \%$ orang tua dengan tingkat pengetahuan baik terkait perkembangan.

Keterbatasan pemahaman orang tua dalam memahami tahapan perkembangan anak berdampak terhadap stimulasi yang diberikan orang tua kepada anak. Kondisi ini sesuai dengan hasil penelitian yang dilakukan oleh (Yusran, Widodo, Kep, \& Setiyawati, 2014) yang menyatakan ada hubungan yang bermakna antara tingkat pengetahuan ibu tentang stimulasi perkembangan dengan perkembangan motorik anak usia 6-24 bulan $(\mathrm{p}=0,000)$. Selain itu keterbatasan pengetahuan orang tua berdampak terhadap sikap orang tua terhadap perkembangan. Hal ini sejalan dengan hasil pengkajian yang dilakukan kepada 115 orang tua di TK Kelurahan yaitu $42 \%$ orang tua dengan sikap yang baik terbatas perkembangan. Keterbatasan pengetahuan dan sikap orang tua terhadap perkembangan sangat berdampak terhadap kemampuan dalam melakukan stimulasi perkembangan. Berdasarkan hasil pengkajian yang dilakukan 
kepada 115 orang tua di lima TK Kelurahan curug teridentifikasi hanya 53\% orang tua yang mampu melakukan stimulasi dengan benar.

Kurangnya pengetahuan, sikap, dan keterampilan orang tua sangat berdampak dalam pemenuhan kebutuhan akan stimulasi pada anak. Belum optimalnya stimulasi perkembangan yang diberikan kepada anak sangat berdampak terhadap tingkat perkembangan anak. Berdasarkan data, diperkirakan anak Indonesia mengalami gangguan perkembangan sebanyak 5-10\% (IDAI). (Yusran et al., 2014) mengungkapkan dari 1000 lahir beresiko 2 anak mengalami gangguan motorik, 3-6 beresiko mengalami gangguan pendengaran, dan 1 anak beresiko mengalami keterlambatan bicara. hasil Anak yang mengalami gangguan perkembangan akan berdampak terhadap kualitas bangsa di masa yang akan datang, seperti meningkatnya tingkat ketergantungan anak. Hasil pemeriksaan tahapan perkembangan dengan form KPSP kepada 118 anak di TK Kelurahan Curug teridentifikasi sebanyak 22\% anak dengan perkembangan yang meragukan.

Teridentifikasinya anak dengan perkembangan meragukan sehingga diperlukan upaya untuk penanganan dalam memberikan stimulasi perkembangan pada anak. Stimulasi perkembangan yang dilakukan dengan dua kegiatan yaitu permainan aktivitas fisik dengan mengacu kepada penelitian (Vazou, Mantis, Luze, \& Krogh, 2017) dan permainan menggambar (Green \& Drewes, 2013).

Anak usia prasekolah termasuk dalam kelompok risiko dengan tiga faktor yang mempengaruhi yaitu risiko dari biologi, risiko dari lingkungan sosial dan lingkungan fisik, serta risiko dari perilaku (Stanhope \& Lancaster, 2019). Berdasarkan risiko biologi pada anak usia prasekolah berkaitan dengan usia anak, karena masih dalam tahapan pertumbuhan dan perkembangan sehingga menyebabkan koordinasi motorik pada anak belum optimal dan berpengaruh terhadap kesehatan anak seperti beresiko terjadinya cedera (Potter, Perry, Hall, \& Stockert, 2013). Faktor yang kedua yaitu dari lingkungan sosial dan lingkungan fisik seperti kondisi perekonomian, sosial budaya, lingkungan pendidikan (Stanhope \& Lancaster, 2019). Faktor ini sangat berpengaruh terhadap pemenuhan stimulasi perkembangan bagi anak usia prasekolah yang dilakukan oleh orang tua. Faktor yang ketiga adalah risiko dari perilaku. Perilaku berisiko dikaitkan dengan perilaku keluarga diantaranya pemenuhan nutrisi pada anak, pemenuhan kebutuhan istirahat tidur, serta pemenuhan stimulasi dimana sangat berdampak terhadap perkembangan anak (Potter, A., \& Perry, 2012).

Perkembangan anak usia prasekolah pada saat anak berusia tiga tahun hingga lima tahun (Potter, Perry, Hall, \& Stockert, 2013). Berdasarkan Peraturan Bersama Menteri Pendidikan dan Kebudayaan Republik Indonesia dan Menteri Agama Republik Indonesia Nomor 2/VII/PB/2014 dengan Nomor 7 Tahun 2014 menyatakan satuan pendidikan anak usia dini pada jalur pendidikan formal yang menyelenggarakan program pendidikan bagi anak berusia empat tahun sampai enam tahun. Usia anak prasekolah di Indonesia dimulai dari usia tiga tahun hingga 6 tahun. Tahapan perkembangan pada anak usia prasekolah terdiri atas empat sektor yaitu perkembangan motorik kasar, motorik halus, personal sosial, dan kemampuan bahasa. 
Sektor motorik kasar yaitu kemampuan anak untuk melakukan gerakan sederhana hingga memiliki kemampuan dalam berlari (Santrock, 2011). Sektor motorik halus yaitu kemampuan anak untuk mengambil objek kecil hingga menyusun benda dengan tepat serta koordinasi yang baik antara lengan, tubuh, tangan dan mata (Santrock, 2011). Pada perkembangan sektor bahasa anak usia prasekolah yaitu kemampuan bahasa anak sebanyak 8000 kata -14.000 kata yang digunakan anak untuk menentukan objek, menentukan warna, dan mengungkapkan keinginan (Potter, Perry, Hall, \& Stockert, 2013). Sektor kemampuan personal sosial anak prasekolah dimana anak mulai untuk bersosialisasi dengan teman sebayanya.

Pemberian stimulasi perkembangan pada anak harus dengan adanya rasa kasih sayang, menunjukkan sikap dan perilaku yang baik, menyesuaikan usia anak, stimulasi dengan permainan dan alat yang berada di sekitar, kesempatan yang sama antara anak laki-laki dan perempuan, serta memberikan pujian pada anak. Stimulasi yang diberikan dengan tepat dan konsisten akan menciptakan perkembangan yang optimal pada anak. Pencapaian perkembangan anak yang optimal selain dengan stimulasi perkembangan juga dengan pemeriksaan perkembangan secara berkala yaitu tiap 6 bulan sekali pada anak berusia 24-72 bulan (Kemenkes RI, 2016).

Pemeriksaan perkembangan di Indoensia dengan menggunakan form KPSP (Kuesioner Pra Skrining Perkembangan). Pemeriksaan perkembangan dengan KPSP disesuaikan dengan usia anak dalam perhitungan bulan dengan jumlah pertanyaan 9-10 yang terbagi menjadi 4 sektor. Hasil pemeriksaan diinterpretasikan menjadi 3 bagian yaitu perkembangan yang sesuai dengan skor 9-10, perkembangan yang meragukan dengan skor 7-8, dan perkembangan dengan penyimpangan dengan skor 6 atau kurang (Kemenkes RI, 2016b).

Stimulasi perkembangan pada anak usia prasekolah dapat dilakukan dengan permainan aktivitas fisik yang berdampak positif terhadap kesehatan anak. Pernyataan ini didukukung dari hasil penelitian yang dilakukan oleh (Wasenius et al., 2018) yang melakukan penelitian selama 3 bulan pada anak usia prasekolah. Pada penilitian ini anak-anak dilakukan kegiatan terstruktur untuk melakukan aktivitas fisik selama 60 menit/hari dengan menggunakan musik. Hasil penelitian ini menunjukkan bahwa ada peningkatan pada kemampuan gerak motorik kasar anak seperti berlari, berjalan, melompat, serta adanya peningkatan pada motorik halus berupa kemampuan mengontrol objek. Kegiatan aktivitas fisik juga berdampak terhadap kemampuan psikomotor, kognitif, dan sosial emosional anak. Metode aktivitas fisik yang dikembangkan oleh (Vazou et al., 2017) terdiri atas enam sesi. Hasil penelitian ini menyatakan adanya peningkatan kemampuan pada anak.

Stimulasi perkembangan yang kedua yaitu dengan mengajarkan menggambar pada anak usia prasekolah. Metode mengambar dapat dilakukan dengan berbagai metode yaitu (Bowman, 2013):

a. mengambar dengan menggunakan alat untuk mengambar dengan objek yang ditentukan atau anak berkreasi sendiri

b. membuat bingkai lukisan dengan bahan kardus dan anak mengambar didalamnya 
c. mengambar dengan menggunakan stempel yang telah dibentuk sesuai dengan tema yang ditentukan

d. mengambar dengan menggunakan jari yang telah dicelup ke alat pewarna

e. anak memberikan warna pada bentuk geometric.

Stimulasi menggambar pada anak usia prasekolah akan disesuaikan dengan kemampuan dan tujuan dilakukan kegiatan pada anak khususnya dalam peningkatan kemampuan motorik halus anak dan kemampuan sosialisasi anak terhadap teman anak.

\section{Metode Penelitian}

Metode yang digunakan dalam kegiatan ini adalah studi kasus berupa stimulasi perkembangan dilakukan pada 118 anak usia prasekolah di lima TK Kelurahan Curug dengan kegiatan permainan aktivitas fisik dan mengambar.Kegiatan stimulasi perkembangan dalam sesi permainan aktivitas fisik dilakukan sebanyak enam sesi dengan waktu 30 menit. Pada tiap sesi terbagi tiga tahapan yaitu tahapan pertama selama 2 menit yaitu perkenalan dan penjelasan intruksi permainan. Tahapan kedua selama 25 menit yaitu permaian sesuai dengan sesi yang dilakukan. Tahapan ketiga 3 menit yaitu sesi evaluasi dari permainan. Permainan ini dilakukan 1 minggu sekali di tiap TK.

Sesi pertama dengan permainan menempel burung. Pada sesi ini anak diminta untuk belari dengan berlomba untuk menempel burung di pohon, memberi makan kepada burung-burung sesuai dengan warna yang disebutkan, serta diminta untuk menyebutkan nama buah yang ditempel. Sesi kedua yaitu permainan menangkap gajah untuk melatih kerjasama anak. Disaat menangkap gajah ada beberapa intruksi yang disesuaikan dengan tahap perkembangan anak. Kemudian secara bergantian anak bertukar peran menjadi gajah dan pemburu. Sesi yang ketiga yaitu grup warna yaitu tiap anak berdiri sesuai kelompok warna kemudian berjalan berputar sesuai dengan lagu yang diputar. Kemudian saat lagu yang diberhentikan maka pemimpin akan mengatakan salah satu warna untuk berpindah tempat.

Permainan sesi keempat yaitu permainan lebah. Permainan ini Anak-anak menari sesuai dengan lagu yang diputar. Ketika lagu diberhentikan maka perawat akan berkata dagu teman, maka anak-anak secara berpasangan akan memegang dagu. Kemudian lagu akan diputar dan anak mengikuti irama lagu. Permainan dengan sesi kelima yaitu tangkap bola yaitu anak-anak bekerja sama untuk saling melempar dan menangkap bola dengan diiringi lagu. Ketika lagu dihentikan anak yang memegang bola akan menangkap anak yang tidak memegang bola. Permainan sesi keenam yaitu anak hebat dengan kegiatan perawat membacakan cerita tentang anak hebat. Disaat perawat cerita anak-anak diminta untuk memperagakan intruksi yang diminta sesuai dengan cerita.

Stimulasi yang kedua yaitu dengan aktivitas mengambar dengan pola yang ditentukan. Stimulasi ini dilakukan selama 1 sesi dengan waktu 30 menit. Pada 1 sesi terbagi menjadi 3 tahapan kegiatan kegiatan. Pada tahapan pertama 2 menit pertama yaitu perkenalan dan penjelasan permainan, tahapan kedua yaitu aktivitas seni berupa 
menggambar selama 25 menit. Tahapan ketiga yaitu evaluasi dengan kegiatan anak menjelaskan tentang gambar.

Evaluasi yang dilakukan pada program "sahabat" yaitu menilai tingkat perkembangan anak dengan menggunakan form KPSP yang disesuaikan dengan usia anak pada saat dilakukan pemeriksaan. Evaluasi kegiatan dilakukan setelah dilakukan intervensi selama 8 bulan.

\section{Hasil dan Pembahasan}

\section{A. Hasil Penelitian}

Hasil kegiatan dari stimulasi perkembangan terhadap perkembangan anak menimbulkan dampak positif yaitu peningkatan perkembangan anak yang sesuai dengan tahapan perkembangannya (Diagram 1).

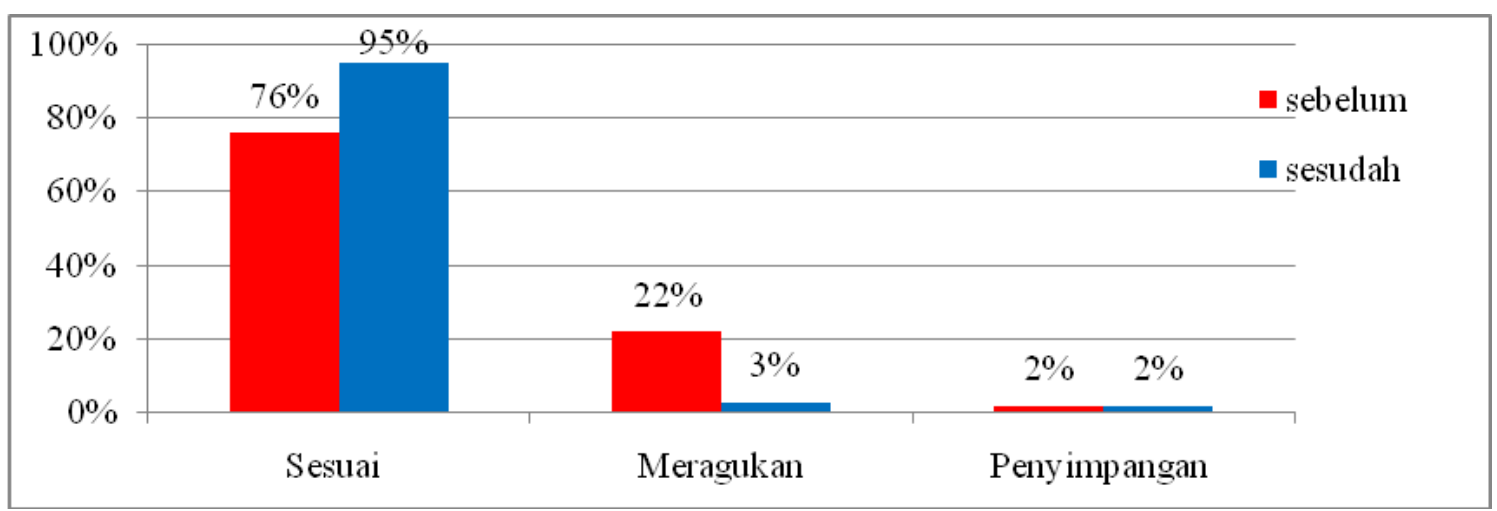

Diagram 1

Gambaran Tahapan Perkembangan Sebelum Dan Sesudah Intervensi Keperawatan

$(\mathbf{N}=118)$

Berdasarkan diagram tersebut digambarkan adanya peningkatan perkembangan pada anak usia prasekolah sebanyak 19\%. Peningkatan perkembangan anak terjadi pada anak dengan perkembangan sebelumnya berada pada tahap meragukan.

\section{B. Pembahasan}

Peningkatan perkembangan ini dipengaruhi adanya stimulasi perkembangan yang diberikan secara komprehensif yang dilakukan pada anak usia prasekolah di TK dengan kegiatan aktivitas fisik. Stimulasi perkembangan berupa aktivitas fisik yang dilakukan dengan komprehesif berdampak terhadap kesehatan anak yaitu perkembangan anak yang sesuai dengan tujuan dari asuhan keperawatan. Hal ini berdasarkan hasil penelitian yang dilakukan selama 3 bulan pada anak usia prasekolah dengan melakukan kegiatan terstruktur berupa aktivitas fisik dengan musik (Wasenius et al., 2018). Hasil penelitian ini menyatakan ada peningkatan pada kemampuan gerak motorik kasar anak seperti berlari, melompat,dan peningkatan motorik halus yaitu kemampuan anak-anak untuk mengontrol objek yang diberikan. 
Aktivitas fisik memiliki dampak positif terhadap perkembangan anak, sehingga aktivitas fisik dapat digunakan sebagai stimulasi perkembangan di sekolah. Aktivitas fisik yang berfungsi sebagai stimulasi pada anak harus disesuaikan dengan metode pembelajaran kepada anak usia dini dan tahapan perkembangan anak. Pendekatan dalam pembelajaran yang digunakan adalah dengan bermain yang dirancang dengan menyenangkan, fungsional, dan efektif sebagai pembelajaran anak. Penelitian yang dilakukan oleh (Vazou et al., 2017) yang melakukan kegiatan aktivitas fisik pada 27 anak usia prasekolah. Kegiatan aktivitas fisik dilakukan sebanyak enam sesi yang bertujuan untuk merangsang kemampuan psikomotor, kemampuan kognitif, dan kemampuan sosial emosional. Hasil penelitian ini mengungkapkan bahwa adanya peningkatan kemampuan secara menyeluruh pada anak usia prasekolah setelah dilakukan kegiatan aktivitas fisik selama 12 minggu secara komprehensif.

Pemberian aktivitas fisik yang berdampak positif terhadap perkembangan sehingga perawat komunitas akan memberikan intervensi keperawatan berupa aktivitas fisik. Kegiatan aktivitas fisik merupakan pengembangan dari intervensi yang dilakukan oleh (Vazou et al., 2017). Aktivitas fisik yang dilakukan dengan sebanyak 6 sesi yang dikombinasikan dengan tahapan perkembangan berdasarkan (Kemenkes, 2016). Tahapan perkembangan yang digunakan dalam akivitas fisik ini berupa tugas yang diminta untuk anak menyelesaikan disaat kegiatan aktvitas fisik. Pemilihan tugas perkembangan dari (Kemenkes RI, 2016) karena sesuai dengan kondisi perkembangan anak Indonesia pada umumnya, karena salah satu faktor yang mempengaruhi perkembangan adalah ras.

Kegiatan stimulasi yang kedua adalah mengambar. Mengambar merupakan salah satu metode yang menarik bagi anak dan tidak mengeluarkan biaya mahal. Berdasarkan hasil penelitian yang dilakukan (Sudarsih et al., 2014) yang melakukan kegiatan mengambar kepada anak selama 4 hari dengan durasi waktu satu jam diperoleh hasil bahwa adanya peningkatan motorik halus anak setelah dilakukan kegiatan. Mengambar juga merupakan salah satu metode untuk anak berekspresi karena dengan megambar anak dapat mengungkapkan bahasa non verbal anak (Ligorio, Schwartz, D’Aprile, \& Philhour, 2017). Hasil ini sesuai dengan penelitian yang dilakukan yang mengungkapkan adanya peningkatan kemampuan motorik halus pada anak usia prasekolah dengan kemampuan menggambar manusia dengan 6 bagian tubuh. Kegiatan menggambar pada anak usia prasekolah berdampak positif karena meningkatkan koordinasi antara mata dan tangan selain itu anak mampu mengembangkan daya imajinatif yang berdampak terhadap kognitif anak (Deák \& Wiseheart, 2015).

Keterbatasan dalam pelaksanaan simulasi perkembangan yaitu memerlukan fasilitator yang banyak karena untuk menilai setiap kemampuan anak dalam kegiatan. Hal ini diantisipasi dengan pelibatan guru sebagai fasilitator. Keterbatasan lainnya sesi permainan panjang sehingga diperlukan waktu untuk melakukan intervensi serta sekolah yang digunakan lebih dari satu. Untuk mengantisipasi hal ini 
perawat berkoordinasi terlebih dahulu untuk pembuatan kontrak jadwal sehingga terbentuk jadwal secara rutin di tiap sekolah untuk melakukan kegiatan. Keterbatasan lainnya dalam penggunaan form KPSP yang tidak sesuai dengan aktivitas anak, dalam mengatasi ini perawat mencoba untuk mengatikan pertanyaan yang sesuai dengan tahapan perkembangannya.

\section{Kesimpulan}

Stimulasi perkembangan berupa permainan aktivitas fisik dan menggambar merupakan metode yang efektif dalam mestimulasi perkembangan pada anak usia prasekolah. Hal ini dibuktikan dengan adanya peningkatan perkembangan pada anak dengan tahapan perkembangan yang meragukan. 


\section{BIBLIOGRAFI}

Bowman. (2013). Montessori at home. Bradeton FL.

Deák, Gedeon O., \& Wiseheart, Melody. (2015). Cognitive flexibility in young children: General or task-specific capacity? Journal of Experimental Child Psychology, 138, 31-53.

Green, Eric J., \& Drewes, Athena A. (2013). Integrating expressive arts and play therapy with children and adolescents. John Wiley \& Sons.

Kemenkes, R. I. (2016). Profl Kesehatan RI Tahun 2016. Jakarta, Kementrian Kesehatan RI.

Kemenkes RI. (2016). Buku kesehatan ibu dan anak. Jakarta: Kemenkes dan JICA.

Kemenkes RI. (2016). Stimulasi, deteksi dan lntervensi dini tumbuh kembang anak. Jakarta: Kemenkes.

Ligorio, Maria Beatrice, Schwartz, Neil H., D’Aprile, Gianvito, \& Philhour, David. (2017). Children's representations of learning through drawings. Learning, Culture and Social Interaction, 12, 133-148.

Potter, A., \& Perry, A. (2012). Fundamental Keperawatan (7th ed.). Jakarta: EGC.

Potter, Patricia A., Perry, Anne Griffin Ed, Hall, Amy Ed, \& Stockert, Patricia A. (2009). Fundamentals of nursing. Elsevier mosby.

Santrock, John W. (2011). Life-span development 13th edition. New York: McGrawHill. Schunk, DH (2005). Self-Regulated Learning: The Educational Legacy of Paul R. Pintrich. Educational Psychologist, 40(2), 85-94.

Stanhope, Marcia, \& Lancaster, Jeanette. (2019). Public health nursing e-book: Population-centered health care in the community. Elsevier Health Sciences.

Sudarsih, Sudarsih, Syafrial, Syafrial, \& Bahar, Amrul. (2014). Meningkatkan Kemampuan Motorik Halus Anak Melalui Media Bermain Menggambar Dekoratif Pada Kelompok B3 Tk Bhayangkari Kota Curup Kabupaten Rejang Lebong. Universitas Bengkulu.

Uce, Loeziana. (2017). The golden age: Masa efektif merancang kualitas anak. Bunayya: Jurnal Pendidikan Anak, 1(2), 77-92.

Vazou, Spyridoula, Mantis, Constantine, Luze, Gayle, \& Krogh, Jacqueline S. (2017). Self-perceptions and social-emotional classroom engagement following structured physical activity among preschoolers: A feasibility study. Journal of Sport and Health Science, 6(2), 241-247. 
Wasenius, Niko S., Grattan, Kimberly P., Harvey, Alysha L. J., Naylor, Patti Jean, Goldfield, Gary S., \& Adamo, Kristi B. (2018). The effect of a physical activity intervention on preschoolers' fundamental motor skills-A cluster RCT. Journal of Science and Medicine in Sport, 21(7), 714-719.

Yusran, Yusran, Widodo, Arif, Kep, A., \& Setiyawati, Wiwik. (2014). Pengaruh pendidikan kesehatan terhadap pengetahuan dan sikap ibu dalam mengoptimalkan pencapaian tumbuh kembang anak pra sekolah di kecamatan kartasura. Universitas Muhammadiyah Surakarta. 